\title{
Outside the Lines: Innovations in Researching Giftedness
}

\author{
Guest Editors \\ Marion Porath and Pamela Richardson \\ The University of British Columbia
}

This special issue focuses on the reconceptualization of giftedness. Five papers explore how we define, identify, research, and support gifts and talents. As guest editors, this has been a very exciting project. It began as a symposium at the Canadian Society for the Study of Education in 2008. Our passion for challenging the status quo, questioning what is 'inside the lines' of current definitions of and research into giftedness, and doing so in forms that are themselves 'outside the lines' prompted further exploration and writing. The papers highlight the possibilities of plurality in how we approach research and represent knowledge (Eisner, 1997; Shore \& Friedman, 2000) both in their form and their content. In hand with this, we resist, as Cross (2003) cautioned, the "correct" conception of giftedness and instead support "understanding of the various ways people think about inquiry or research and how this relates" (p. 77) to our conceptualizations and understandings of giftedness. Present in these papers are poetic analysis; children's perceptions of learning identities expressed in drawings, poems, and music; narrative; metaphors; and pedagogical analysis via documentation of learning, all of which provoke thinking about research and education that promote the realization of all children's potential.

The last two decades of the $20^{\text {th }}$ century were characterized by efforts designed to encourage the reconsideration and expansion of our definitions of giftedness to allow for the multiple ways in which one can be competent (e.g., Gardner, 1983). As we enter the $21^{\text {st }}$ century, these efforts have broadened to include 'gift creation' rather than identification (Hymer, 2009; Hymer, Whitehead, \& Huxtable, 2009); the role of the learner in defining directions for education (Hymer et al., 2009); questions about the construct of 'giftedness' (Balchin, Hymer, \& Matthews, 2009; Borland, 2003; Horowitz, Subotnik, \& Matthews, 2009); and the role of the learning environment in provoking and realizing potential (Barab \& Plucker, 2002; Borland, 2003; Hymer et al., 2009).

Now, more attention is directed to cultural influences on valued competencies (Sternberg \& Grigorenko, 2004), factors important to extraordinary competence that move "beyond knowledge" (Shavinina \& Ferrari, 2004), and the role of rich, complex environments in the determination and support of competent behaviours (Barab \& Plucker, 2002). Intelligence is situated in context, demanding multiple views of giftedness consonant with our pluralistic society and global community, recognition and support of "nontraditional" talents, and multiple representations of what it means to realize and understand competence.

Porath and Lupart's paper presents gifted children's perceptions of themselves as readers, writers, mathematicians, and other identities of their choice (e.g., artist, athlete). These perceptions of learning identities are represented in a variety of forms, highlighting the multiple ways in 
which knowledge can be expressed (Eisner, 2008). Lai's paper highlights the research practice gap where reconceptualization of giftedness has not resulted in reconceptualization of gifted programs. Her discussion of the implications of the Reggio Emilia approach for early discovery and support of different forms of giftedness highlights the roles of rich context, educational philosophy, and careful documentation of learning in actualizing potential.

Fogel's paper describes a qualitative exploration of the perceived experiences of scientists who also engage in the arts. This work sheds light on the relevance of the arts in education (Eisner 1991, 2003a, 2003b, 2005) and the historical accounts of eminent scientists who spoke of the importance of artistic spirit in their work. The artistic works of highly able scientists and Fogel's own photographs highlight the important role of the arts in matters related to recognition and development of gifts and talents. They also provide support for the place of extracognitive functions, such as intuition and feelings of beauty (e.g., Shavinina \& Ferrari, 2004), in the realization of giftedness. Moving to cultural views of giftedness and narrative as a vehicle for exploring the development of gifts, Ngara shares an adapted folktale from Zimbabwe that is a rich metaphor for the factors inherent in the development and realization of exceptional performance. In Shona culture of Zimbabwe's implicit theories of giftedness, every child is presumed gifted until proven otherwise. Sharing such stories alerts us to the challenges of identifying gifted students who require special programming.

Richardson's paper presents a powerful metaphor for research in gifted education. The experience of swimming 'past buoy lines' provides a poetic basis for understanding how we position ourselves as researchers and how we conceptualize and relate to the constructs which we purport to investigate. In her artful analysis of a study that surveyed novice to expert researchers in gifted education and psychology about their experiences, hopes, and challenges in the use of "alternative methodologies," Richardson challenges us to think seriously and creatively about what we do and how we do it.

\section{References}

Balchin, T., Hymer, B., \& Matthews, D. J. (2009). The Routledge international companion to gifted education. London: Routledge.

Barab, S. A., \& Plucker, J. A. (2002). Smart people or smart contexts? Cognition, ability, and talent development in an age of situated approaches to knowing and learning. Educational Psychologist, $37,165-182$.

Borland, J. H. (2003). The death of giftedness: Gifted education without gifted children. In J. H. Borland (Ed.), Rethinking gifted education (pp. 105-124). New York: Teachers College Press.

Cross, T. (2003). Rethinking gifted education: A phenomenonological critique of the politics and assumptions of the empirical-analytical mode of inquiry. In J. H. Borland (Ed.), Rethinking gifted education (pp. 72-79). New York: Teachers College Press.

Eisner, E. (1991). What really counts in schools. Educational Leadership, 48(5), 10-17.

Eisner, E. W. (1997). The new frontier in qualitative research methodology. Qualitative Inquiry, 3, 259273.

Eisner, E. W. (2003a). Artistry in education. Scandinavian Journal of Educational Research, 47(3), 373384.

Eisner, E. W. (2003b). The arts and the creation of mind. Language Arts, 80(5), 340-344.

Eisner, E. (2005). Back to whole. Educational Leadership, 63(1), 14-18.

Eisner, E. (2008). Art and knowledge. In J. G. Knowles \& A. L. Cole (Eds.), Handbook of the arts in qualitative research (pp. 3-12). Los Angeles: Sage.

Gardner, H. (1983). Frames of mind: The theory of multiple intelligences. New York: Basic Books. 
Horowitz, F. D., Subotnik, R. E., \& Matthews, D. J. (2009). The development of giftedness and talent across the life span. Washington, DC: American Psychological Association.

Hymer, B. J. (2009). Beyond compare? Thoughts towards an inclusional, fluid and non-normative understanding of giftedness. In T. Balchin, B. Hymer, \& D. J. Matthews (Eds.), The Routledge international companion to gifted education (pp. 299-307). London: Routledge.

Hymer, B., Whitehead, J., \& Huxtable, M. (2009). Gifts, talents and education: A living theory approach. Chichester, UK: Wiley-Blackwell.

Shavinina, L. S., \& Ferrari, M. (2004). Beyond knowledge: Extracognitive aspects of developing high ability. Mahwah, NJ: Erlbaum.

Shore, B. M., \& Friedman, R. C. (2000). Introduction. In R. C. Friedman \& B. M. Shore (Eds.), Talents unfolding: Cognition and development (pp. xv-xix). Washington, DC: American Psychological Association.

Sternberg, R. J., \& Grigorenko, E. L. (2004). Culture and competence: Contexts of life success. Washington, DC: American Psychological Association.

\section{Authors' Notes}

We would like to thank Laurence Coleman, Dona Matthews, Jean Peterson, and Carl Leggo for their supportive and insightful reviews. They pushed us that important distance forward in refining and elaborating our thinking about giftedness, research, and the ways in which we discover and support exceptional potential. Special thanks go to Dona Matthews for providing the provocation for the title of this special issue. 